\title{
Germination, Vigor of Seeds and Emergence of Fabaceae Seedling in Bovine Faeces
}

\author{
Renata Vianna Lima ${ }^{1}$, Henrique Duarte Vieira ${ }^{1}$, Francielle de Souza Guimarães', \\ Nardele Moreno Rohem Jr. ${ }^{2}$, Tatiana Oliveira da Silva1, Alberto Magno Fernandes ${ }^{2}$, \\ Cynthia Pires Guimarães ${ }^{1}$, Amanda Justino Acha1, Bruno Borges Deminicis ${ }^{1}$ \\ ${ }^{1}$ Department of Fitotecnia, State University of North Fluminense Darcy Ribeiro (UENF), Campos dos Goytacazes, \\ Rio de Janeiro, Brazil \\ ${ }^{2}$ Department of Zootecnia, State University of North Fluminense Darcy Ribeiro (UENF), Campos dos Goytacazes, \\ Rio de Janeiro, Brazil \\ Email: renataviannalima2005@yahoo.com.br
}

Received 13 May 2014; revised 10 June 2014; accepted 26 June 2014

Copyright (C) 2014 by authors and Scientific Research Publishing Inc.

This work is licensed under the Creative Commons Attribution International License (CC BY).

http://creativecommons.org/licenses/by/4.0/

\section{(c) (i) Open Access}

\begin{abstract}
This study was conducted to evaluate the physiological quality of forage seeds after passage through the gastrointestinal tract of cattle, as well as the emergence of seedlings derived from these seeds. Three Fabaceae species were used: tropical kudzu, leucaena and calopo. One hundred grams of seeds of each species were offered, separately, to five bovines. After the start of the dispersion, the faeces of the animals were collected every 6 hours, in a total of 72 hours, being taken to the greenhouse immediately after each collection. The study evaluated the total number of seedlings in the stool, the lengths of roots and aerial parts, as well as the natural and dry seedling weight thirty days after the disposal of the faeces in the greenhouse. The experimental design consisted of randomized blocks, with twelve treatments (sampling periods) and five replications (cattle). The best performance for the total number of seedlings in the faeces of cattle was observed in the kudzu species. The length of the root, length of the aerial part and dry matter seedling weight was observed in the leucaena species, followed by kudzu. The calopo showed low results for all variables due to the high degradation of the seeds.
\end{abstract}

\section{Keywords}

Pueraria phaseoloides, Leucaena leucocephala, Calopogonium mucunoides, Dispersal, Physiological Quality

\section{Introduction}

Domestic animals, such as bovines, contribute to the maintenance of ecosystems, providing services such as

How to cite this paper: Lima, R.V., Vieira, H.D., de Souza Guimarães, F., Rohem Jr., N.M., da Silva, T.O., Fernandes, A.M., Guimarães, C.P., Acha, A.J. and Deminicis, B.B. (2014) Germination, Vigor of Seeds and Emergence of Fabaceae Seedling in Bovine Faeces. American Journal of Plant Sciences, 5, 2170-2177. http://dx.doi.org/10.4236/ajps.2014.514230 
seed dispersal and nutrient cycling or simply assuring their economical sustainability [1].

Seed dispersal has its importance to the diversity of our pastures. The inclusion of Fabaceae in Poaceae-exclusive pastures represents a food source from a nutritional—for they present high protein content and good digestibility—and strategic — for they store green food in the dry season—point of view. Besides these, other advantages can be mentioned, such as nitrogen fixation, nutrient recycling and the recovery of pastures or degraded areas.

However, a major obstacle in the adoption of mixed pastures of Poaceae and Fabaceae is the cost of their deployment to the operating system [2].

Studies that emphasize seed dispersal by animals in pastures have real importance, for not much is known about this process. Furthermore, there is still little knowledge about the proportion of seeds that remain viable after passing through the digestive tract of animals [3] [4].

In the process of seed ingestion by animals, damages are caused through chewing and digestion, and, in these conditions, a higher or lower percentage of germination depends on the size and shape of the ingested seeds. Reference [5] states that preliminary studies have shown that small, rounded seeds have a higher likelihood of surviving ingestion and passing through the gastrointestinal tract (GIT) than bigger, elongated seeds.

In addition to the factors regarding the passage through GIT, seed germination in faecal plates can be influenced by the fermentation of the stool sample, by high fungal or bacterial contamination, by the positioning of the seeds in the faecal matter, and by the dehydration of the faecal matter.

The seeds that survive the passage through GIT are benefitted by the great amount of nutrients available in the faeces [6]. Subsequently, these nutrients are still useful to seedlings. On the other hand, seed germination and seedling establishment can be inhibited due to the toxicity and hydrophobic nature of the faecal matter [7].

The importance of natural sowing is acknowledged in the renovation and persistence of the species in pastures. Therefore, it is necessary to understand more deeply the behavior of seeds excreted by bovines in order to evaluate the dynamics of forage-seed dissemination [8] [9].

According to these considerations, this research was conducted with the objective of evaluating the physiological quality of seeds of the forages: tropical kudzu (Pueraria phaseoloides Benth), leucaena (Leucaena leucocephala), and calopo (Calopogonium mucunoides), after the passage through GIT, as well as the emergence of seedlings from these seeds.

\section{Material and Methods}

This study was carried out with seeds from three forage species of the Fabaceae family: tropical kudzu (Pueraria phaseoloides Benth), leucaena (Leucaena leucocephala), and calopo (Calopogonium mucunoides), whose plots were previously analyzed regarding germination and vigor, following the recommendations of the Rules for Seed Testing [10].

Five bovines, with average weight of $238 \mathrm{~kg}$, were accommodated in individual stalls to facilitate the collection o faeces. The period for the animals to adapt to the housing and diet alterations was of seven days. The feeding was carried out individually, following a 90:10 voluminous-concentrate ratio, with $1 \mathrm{~kg} / \mathrm{day}$ of corn meal and soy meal concentrate, $10 \mathrm{~kg} /$ day of tifton grass hay — which was divided into two daily feedings-, and water at will. The diet was balanced following the nutrient requirements of small ruminants-NRC-[11] to suppress the maintaining requirements.

One hundred grams of seeds of each Fabaceae were mixed with $1 \mathrm{~kg}$ concentrate and given to the animals, once a day, in the morning (6:00 a.m.) on the first day only. This amount corresponds to, approximately, 8695 kudzu tropical seeds, 1530 leucaena seeds, and 6896 calopo seeds [10], all intact.

The faeces were collected every 6 hours after the total ingestion of the seeds $(12,18,24,30,36,42,48,54,60$, 66, and 72 hours). The rejects from the first 6 hours were disregarded, for no seeds were observed in this period in preliminary essays. For the control test (0 hour), four repetitions were carried out, with one hundred seeds of each species in direct contact with the commercial substrate Basaplant, in plastic trays, without going through GIT.

After collection, the faeces were packaged in tagged plastic bags and taken to the greenhouse, where they were disposed in rectangular plastic trays $(61 \mathrm{~cm}$ length, $40 \mathrm{~cm}$ width, $10 \mathrm{~cm}$ height), identified and punctured to enable the drainage of water excess. The trays were covered with a layer of the commercial substrate Basaplant to simulate soil. The faeces were deposited in the trays over the substrate according to the collecting periods and stayed for thirty days. During this time, the samples were watered at least twice a day. The averages for maximum 
and minimum temperatures in the greenhouse for the experimental period were of $32.2^{\circ} \mathrm{C}$ and $20.3^{\circ} \mathrm{C}$, respectively.

The emerged seedlings were counted daily, and, at the end of the thirty days, they were removed from the faeces and weighted in their integrity (aerial part and roots) for the natural weight. For the dry weight, the seedling were packaged in tagged paper bags and disposed in a forced ventilation greenhouse, at $70^{\circ} \mathrm{C}$, for 72 hours.

\section{Statistical Analyses}

The species were analyzed separately, and the chosen experimental delineation consisted in a randomized block design, with twelve treatments (collecting periods) and five repetitions (bovines). The results were submitted to the analysis of variance and to Duncan's test, with a significance of $5 \%$ for the grouping of the averages, through the statistical software Assistant.

\section{Results and Discussion}

In Figure 1(a), it is observed that the kudzu species presented a growing number of seedlings emerged in faeces in the periods from 18 to 30 hours after the ingestion of seeds by the bovines, gradually decreasing from this

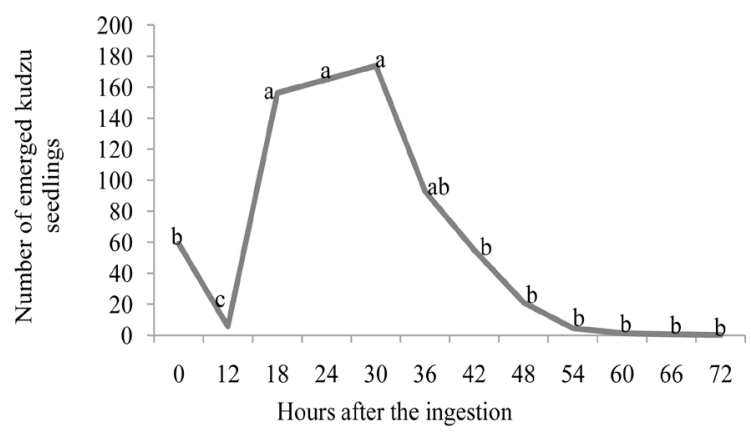

(a)

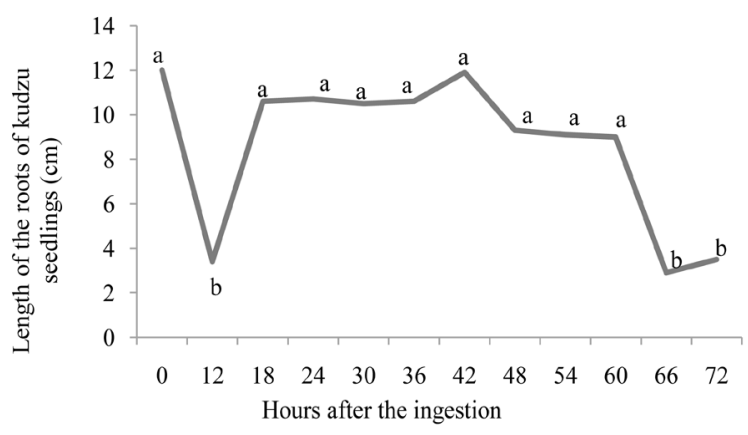

(b)

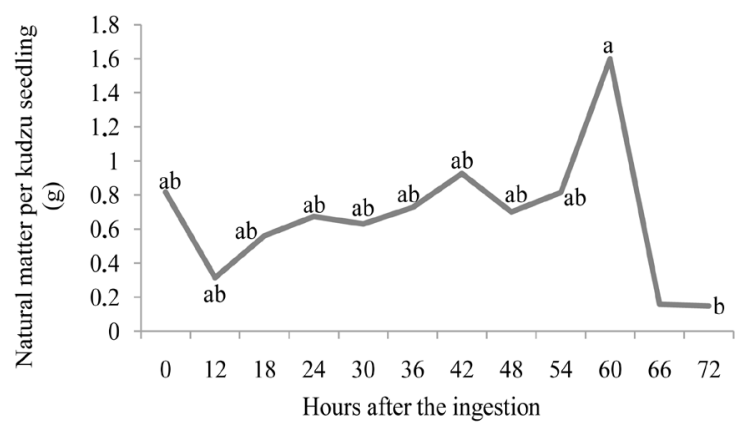

(d)

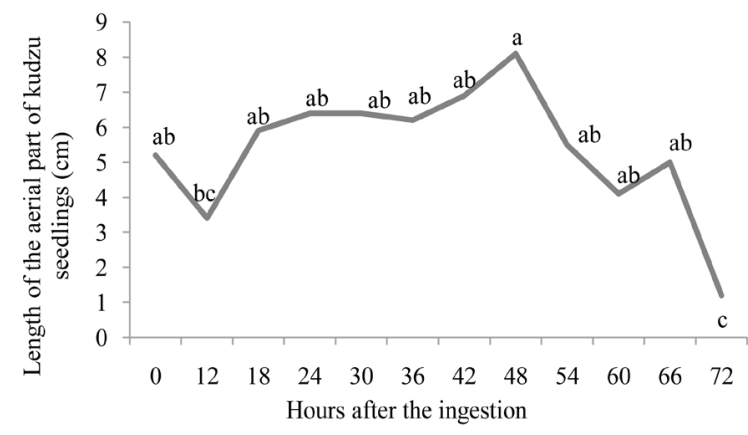

(c)

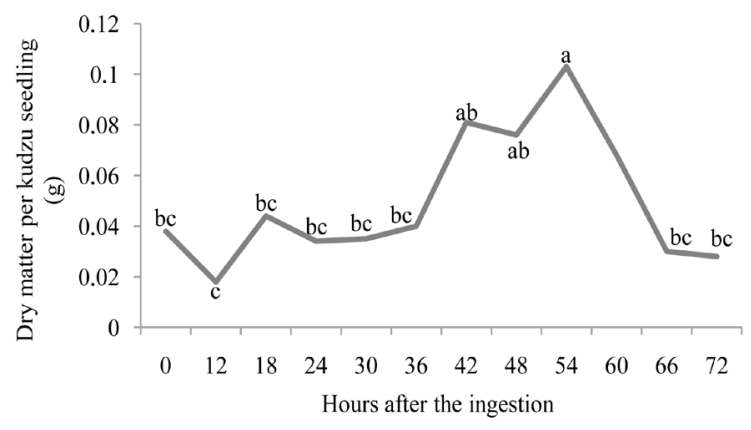

(e)

Figure 1. Number of emerged plants (a), length of the root $(\mathrm{cm})(\mathrm{b})$, length of the aerial part $(\mathrm{cm})(\mathrm{c})$, natural matter $(\mathrm{g})$ (d), and dry matter (g) (e) of kudzu seedlings from seeds that went through bovine GIT. 
period onwards. These results suggest that 30 hours of permanence of kudzu seeds in bovine rumen are effective in augmenting their germination, which evinces the overcoming of the intergumentary dormancy they present. The higher emergence of kudzu seedling in the faeces may be connected to shape and texture of the tegument. According to [12], seeds of smaller length suffer less damage when passing through GIT, and spherical seeds and seeds with smooth skin hinder the damages during the chewing process.

In a similar study about the dispersion of Fabaceae seeds in the faeces of bovines in open fields, [13] also found a higher number of kudzu plants when comparing to macrotiloma, to calopo, and to estilosantes. The author relates these results to the efficiency in overcoming dormancy and degradation in the passage of the seeds through bovine GIT. Additionally, [15] stated that the passage of the seeds through the digestive system of birds that spread seeds increases the percentage of germination and the vigor of Cecropia pachystachya in the cerrado region in central western Brazil.

In an emergency essay on Fabaceae seedlings in bovine faeces, [16] observed an emergence of zero for dwarf pigeon peas. For broad fava beans and calopo, the root protrusion was observed, but not the development of the seedlings. For leuceana, there was an emergence of $10 \%$, but the seedlings were considered abnormal. Reference [17] affirmed that the bovine faeces may have not been in a favorable medium for the initial growth of the seedling of those species and that the medium might have been toxic for the seedlings, mainly due to the possible $\mathrm{pH}$ variations and to nitrogenous compounds created by microbial activity.

For the three studied legumes, we could not observe any seedling in the period of 12 hours, which indicates that the dispersion had not begun in full intensity (Figure 1(a), Figure 2(a) and Figure 3(a)).

Regarding the length of the root and the aerial part of the seedlings, there was a significant difference between the periods after the ingestion of the seeds for all three species. For kudzu, the greater root length were observed between 18 and 60 hours. The greater aerial part length were observed between 18 and 66 hours. For both variables, the results obtained with the dispersion, did not differ from control (Figure 1(b) and Figure 1(c)).

Figures 1(d) and Figure 1(e) show that, for kudzu seedlings, the greater natural matters and dry matter were observed between 18 and 60, and 42 and 54, respectively, after the ingestion of seeds, decreasing afterwards. In the dispersion times of 42, 48 and 54 hours, the kudzu seedlings obtained dry matter significantly greater than the control group. The values for this variable only decreased after 54 hours and onwards, coinciding with the decrease in the emergence of seedlings, which indicates the dispersion was equally starting to decrease or that some seeds in the faeces might have already been dead. According to [18], the digestion is the main cause of the disappearance of the seeds given to the animals and of the lost of its germinative capacity.

From the results of the number of emerged seedlings and natural matter of kudzu seedlings, it was possible to verify that the bovine faeces did not prevent the emergence and the development of this Fabaceae species. The results agree with those found by [19], which affirmed that growth of the seedlings was not hindered from being surrounded by ovine faeces; on the contrary, faeces may provide the plants with greater vigor due to the liberation of nutrients [7].

In Figure 2(a), it is observed that, for the leucaena seeds, the number of emerged seedlings was gradually growing 18 until 30 hours after the ingestion of the seeds until its maximum was reached, decreasing from this point onwards. The leucaena seeds expelled between 18 and 54 hours after the ingestion were the ones that originated bigger seedlings, both for the aerial part and for the root (Figure 2(b) and Figure 2(c)). These results are similar to those found by [16], which observed that the leucaena seeds that went through bovine GIT originated higher seedlings than the intact seeds. For the Cajanus cajan seeds, the passage through bovine GIT reduced the growth rate for the height of the seedlings. The effect was less accentuated in calopo seeds.

Greater natural matter occurred at 18, 24, 30, 36, 42 and 54, and dry matter occurred at 18 until 54 hours after the dispersion of the seeds, with gradual decrease from this point on for both variables. The dry matter decreased after 36 hours of dispersion, coinciding with the fall in seedling emergence (Figure 2(d) and Figure 2(e)).

For the calopo, the greater number of emerged seedlings was observed for the intact seeds, i.e., that did not went through animal GIT and, therefore, there was no significant effect between the dispersion periods (Figure 3(a)). These results agree with those found by [2] with estilosantes in bovine faecal plates, which attributed the low emergence percentage of the estilosantes seedlings to the high degradability in the passage through GIT of the animals.

The calopo seedlings originated from the seeds that went through the bovine gastrointestinal tract were smaller and less developed, i.e., less heavy when compared the seedling originated from intact seeds, evidencing once again the negative effect caused by the passage through GIT, but for seedlings emerged 24 hours after the 


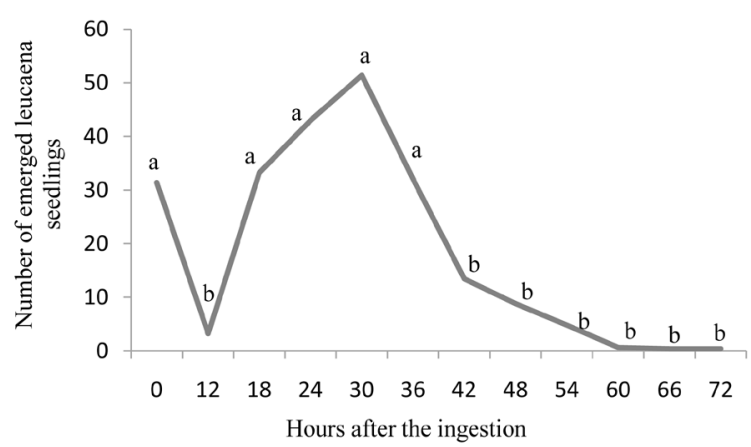

(a)

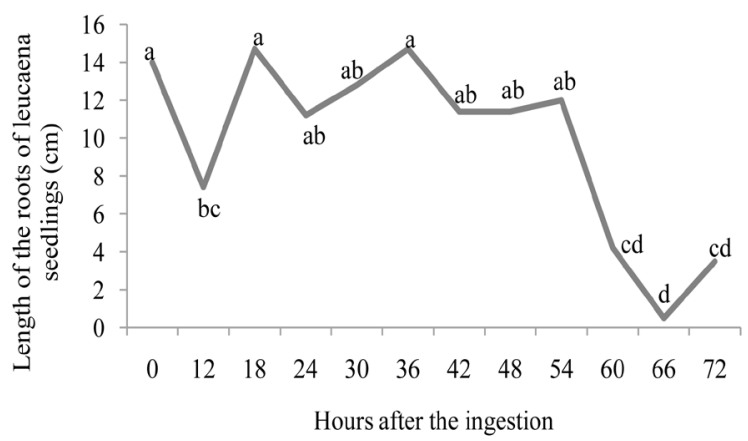

(b)

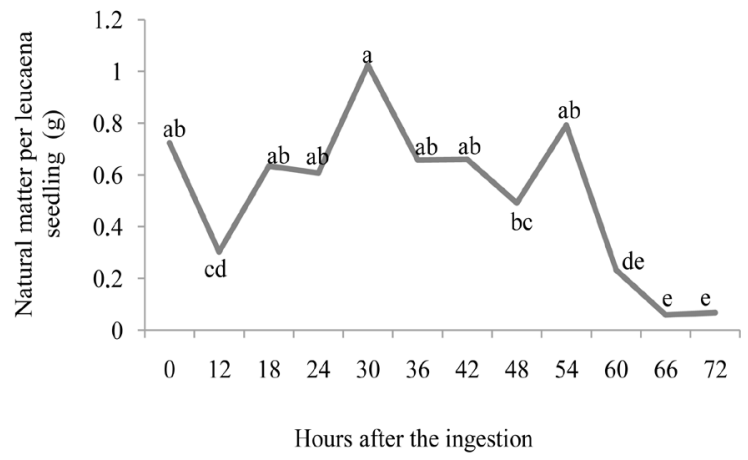

(d)

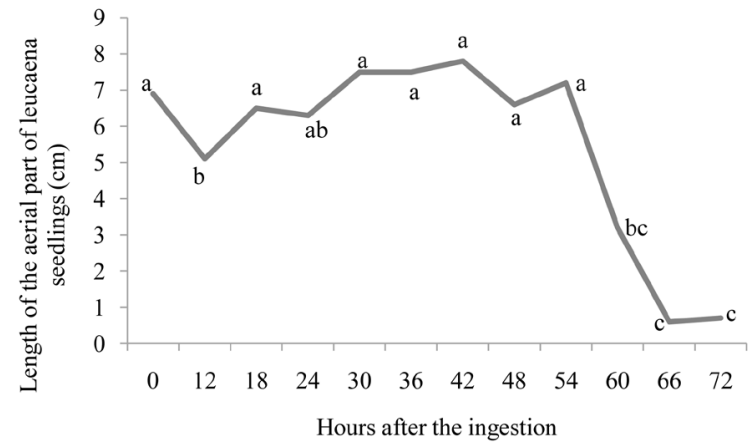

(c)

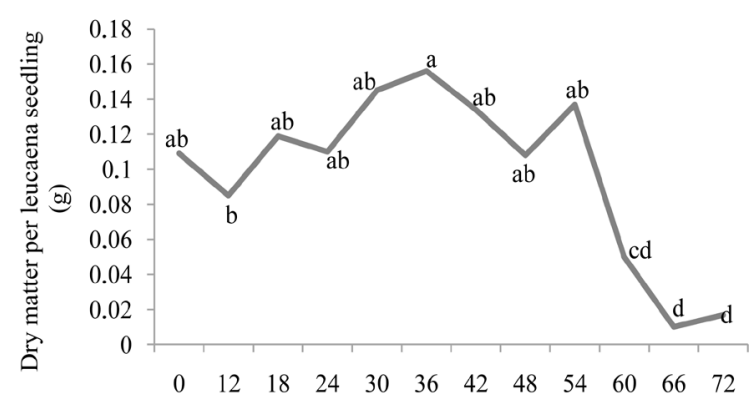

Hours after the ingestion

(e)

Figure 2. Number of emerged plants (a), length of the root $(\mathrm{cm})(\mathrm{b})$, length of the aerial part (cm) (c), natural matter (g) (d), and dry matter (g) (e) of leucaena seedlings from seeds that went through bovine GIT.

ingestion of seeds, whose length of the roots did not differ from control. For the length of the aerial part, seedlings emerged 24, 30, 36 and 42 hours after the ingestion of seeds did not differ from control (Figure 3(b) and Figure 3(c)).

The passage of the calopo seeds through bovine GIT should not constitute a favorable medium to the initial growth of the seedlings, as can be seen by the values of natural and dry matters, whose lengths were smaller from control (Figure 3(d) and Figure 3(e)), bearing in mind the low or inexistent germination in such medium, which may be toxic to the seedlings due to $\mathrm{pH}$ variations and to nitrogenous compounds created by microbial activity. These authors believe that the residence time of the seeds in the faeces has a direct relation with their mortality, in addition to the total dehydration of the faecal plate in two days [17]. Nevertheless, in open field conditions, the stomping, the rain, and, mainly the activity of coprophage beetles may modify the substrate and create a microenvironment that is favorable to the germination of seeds and to the growth of the seedlings deposited in the faeces, in such a way that they do not act as a limiting factor for dispersion [16].

In Table 1, there is the individual response of the studied species. Even though kudzu had the largest number of seeds provided to the animals (8695) and a larger number of emerging seedlings (675), leucaena was the one 


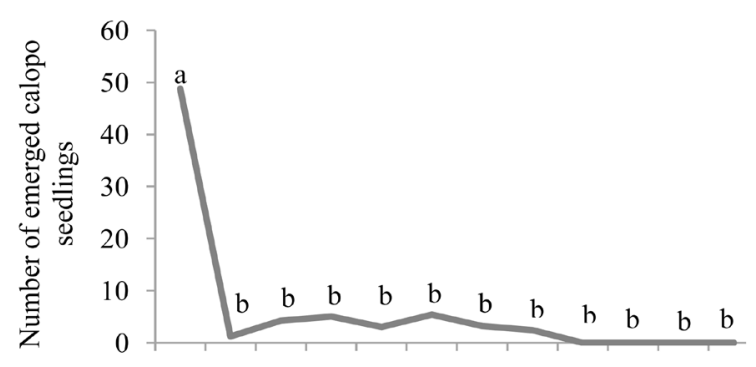

$\begin{array}{llllllllllll}0 & 12 & 18 & 24 & 30 & 36 & 42 & 48 & 54 & 60 & 66 & 72\end{array}$ Hours after the ingestion

(a)

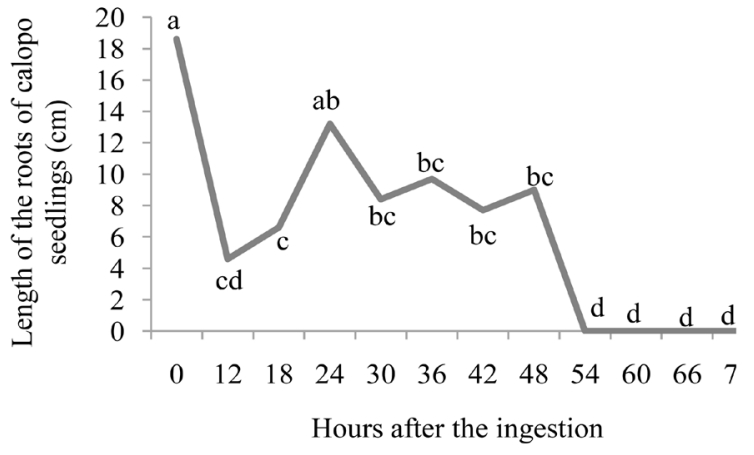

(b)

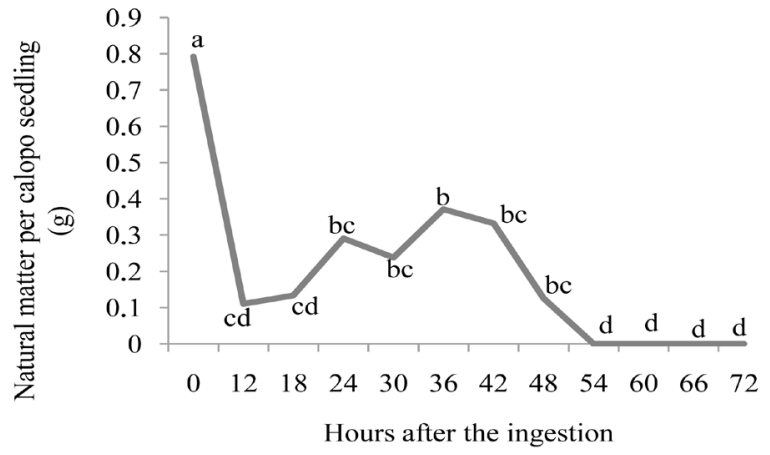

(d)

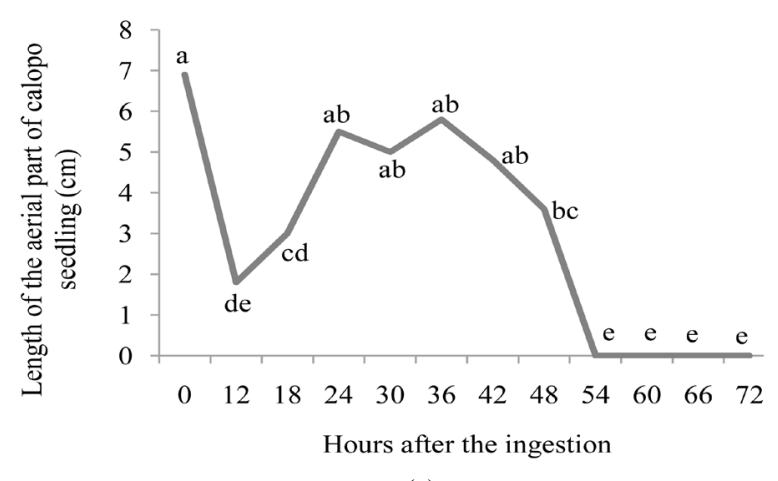

(c)

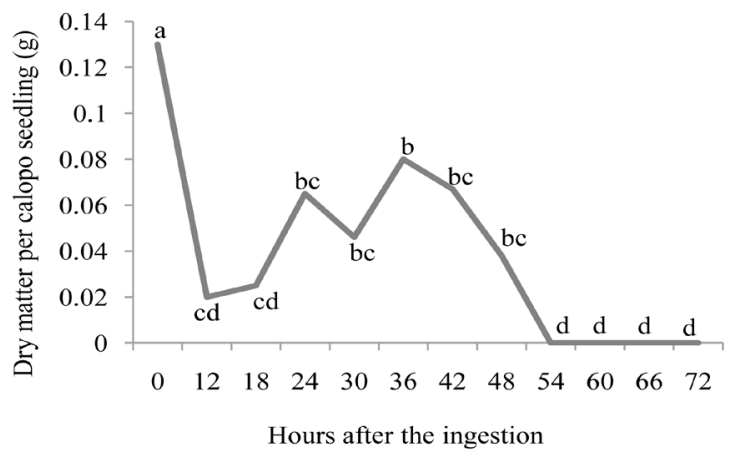

(e)

Figure 3. Number of emerged plants (a), length of the root $(\mathrm{cm})(\mathrm{b})$, length of the aerial part $(\mathrm{cm})(\mathrm{c})$, natural matter $(\mathrm{g})$ (d), and dry matter (g) (e) for calopo seedlings from seeds that went through bovine GIT.

Table 1. Number of seeds given to the animals and of emerged plants, percentage of emerged seedlings, length of the root, length of the aerial part, natural matter and dry matter for kudzu, leucaena and calopo seedlings from seeds that went through bovine GIT.

\begin{tabular}{cccccccc}
\hline & $\begin{array}{c}\text { Number of } \\
\text { seeds given } \\
\text { to the animals }\end{array}$ & $\begin{array}{c}\text { Number } \\
\text { of emerged } \\
\text { seedlings }\end{array}$ & $\begin{array}{c}\text { Percentage } \\
\text { of emerged } \\
\text { seedlings }\end{array}$ & $\begin{array}{c}\text { Length of the } \\
\text { roots }(\mathrm{cm})\end{array}$ & $\begin{array}{c}\text { Length of the } \\
\text { aerial part } \\
\text { (cm) }\end{array}$ & $\begin{array}{c}\text { Natural matter } \\
\text { per seedling } \\
\text { (g) }\end{array}$ & $\begin{array}{c}\text { Dry matter } \\
\text { per seedling } \\
\text { (g) }\end{array}$ \\
\hline Kudzu & 8695 & 675 & 7.8 & 8.6 & 5.4 & 0.67 & 0.05 \\
Leucena & 1530 & 191 & 12.5 & 9.8 & 5.5 & 0.52 & 0.09 \\
Calopogônio & 6896 & 24 & 0.4 & 6.5 & 3.0 & 0.20 & 0.04 \\
\hline
\end{tabular}

with the greatest percentage of seedling emergence (12.5\%) regarding the amount of seeds available to the animals (1530). These results suggest that the leucaena seeds present larger resistance to the conditions encountered in bovine GIT due to the cutaneous hardness inherent to the species. After passing through bovine GIT, the 
leucaena seeds produced seedlings with larger root length and greater dry matter weight, while the length of the aerial part was similar to that of the kudzu seedlings.

In a similar study, [14] reports that the highest percentage of recovery was obtained for kudzu seeds (23\%) and that the lowest percentage of recovery was observed with the Butterfly Pea seeds (16\%); the study attributes this lower recovery to the larger size of the seeds presented by the species. Reference [19] obtained a recovery rate of $50 \%$ for the seeds of five species of the Cistaceae family after the passage through bovine GIT and attributed this high percentage to the small size and hardness of the seed coat, which protected them from damage during the chewing and ruminating.

Reference [2] tendered two hundred intact seeds of each one of the following legumes: Leucaena leucocephala, Clitorea ternatea, Calopogonium mucunoides, Neonotonia wightii, and Macrotiloma axilare. The percentage of emerging seedlings in the faeces was low, ranging between $2.5 \%$ and $8.63 \%$ for the total amount of ingested seeds. In contrast, [16] tendered 9000 seeds of each one of the legumes to cattle: Leucaena leucocephala (Lam.) of Wit, Cajanus cajan (L.) Huth, and Calopogonium mucunoides; it also recovered $12 \%$ of the Cajanus cajan seeds and $17.5 \%$ of the Calopogonium mucunoides seeds. These authors considered the values of this low recovery and attributed to it the damage that the seeds suffered during the ingestion (chewing) and passage through animal GIT.

The passage through bovine GIT severely affected the capacity of the calopo seeds to germinate. As they went through the animal GIT, the seeds increased size due to the imbibition process and presented a rupture on the tegument. Thus, the low percentage of seedling emergence could be related to the softening and deterioration of seeds, caused by hydration within the GIT, which would lead to the loss of viability due to the action of the gastric juice [20] [21].

\section{Conclusions}

Leucaena seeds are less susceptible to damages caused by chewing and degradation in bovine GIT.

The greatest total number of seedlings emerged in faeces was observed in the kudzu species.

The greatest results for the length of the aerial part and the root and for dry matter, observed in the leucaena species, followed by kudzu.

The passage of the calopo seeds through bovine GIT should not constitute a favorable medium to the dispersal.

\section{Acknowledgements}

We thank the "Research Support Foundation of the State of Rio de Janeiro" (FAPERJ).

\section{Clarification}

The proceedings were approved and carried out according to Protocol 207, registered in the Ethics and Animal Use Committee of UENF.

\section{References}

[1] Moura, M.I., Torres, T.F., Monteiro, E.P., Neiva, A.C.G.R., Cardoso, W.S. and Fioravanti, M.C.S. (2011) Evolution of the Curraleiro Cattle Herd Reintroduced in Native Savannah in the Northeast of Goias, Brazil. Actas Iberoamericanas de Conservación Animal, 1, 123-126. http://www.odonto.ufg.br/uploads/133/original_Moura2011_1_123_126.pdf

[2] Deminicis, B.B., Almeida, J.C.C., Malafaia, P.A.M., Blume, M.C., Abreu, J.B.R. and Vieira, H.D. (2009) Germination of Seeds in Bovine Dung. Archivos de Zootecnia, 58, 73-84. http://scielo.isciii.es/scielo.php?script=sci_arttext\&pid=S0004-05922009000100008

[3] Faust, C., Eichberg, C., Storm, C. and Schwabe, A. (2011) Post-Dispersal Impact on Seed Fate by Livestock Trampling -A Gap of Knowledge. Basic and Applied Ecology, 12, 215-226.

http://www.sciencedirect.com/science/article/pii/S1439179111000247 http://dx.doi.org/10.1016/j.baae.2011.02.009

[4] Hittorf, M.R. (2012) Seed Dispersal in Wild Herbivores: Strategies in Sympatric Species. Ph.D. Dissertation, Polytechnic Institute of Bragança, School of Agriculture, Bragança.

[5] Pakeman, R.J., Digneffe, G. and Small, J.L. (2002) Ecological Correlates of Endozoochory by Herbivores. Functional Ecology, 16, 296-304. http://onlinelibrary.wiley.com/doi/10.1046/j.1365-2435.2002.00625.x/full 
http://dx.doi.org/10.1046/j.1365-2435.2002.00625.x

[6] Bruun, H.H. and Poschlod, P. (2006) Why Are Small Seeds Dispersed through Animal Guts: Large Numbers or Seed Size per se? Oikos, 11, 402-411. http://onlinelibrary.wiley.com/doi/10.1111/j.2006.0030-1299.14114.x/full http://dx.doi.org/10.1111/j.2006.0030-1299.14114.x

[7] Traveset, A., Bermejo, T. and Willson, M. (2001) Effect of Manure Composition on Seedling Emergence and Growth of Two Commonshrub Species of Southeast Alaska. Plant Ecology, 155, 29-34.

http://link.springer.com/article/10.1023/A:1013282313035

http://dx.doi.org/10.1023/A:1013282313035

[8] Blackshaw, R.E. and Rode, L.M. (1991) Effect of Ensiling and Rumen Digestion by Cattle on Weed Seed Viability. Weed Science, 39, 104-108.

http://www.jstor.org/discover/10.2307/4045114?uid=37431\&uid=3737664\&uid=5909624\&uid=2\&uid=3\&uid=67\&ui $\mathrm{d}=37430 \& u i d=62 \&$ sid $=21103364101801$

[9] Machado, L.A.Z., Nicoloso, C.S. and Jacques, A.V.A. (1997) Percentage of Germinatìn and the Hardness of the Seed Coat of Theree Pasture Species Recovered from Sheep Peces. Revista Brasileira de Zootecnia, 26, 42-45.

[10] Brasil (2009) Ministry of Agriculture and Agrarian Reform. Rules for Seed Analysis, SNDA/DNDV/CLAV.

[11] Soest, P.J.V. (2007) Nutritional Ecology of the Ruminant. The Nat Aca Press, Washington.

[12] Simão Neto, M., Jones, R.M. and Ratcliff, D. (1987) Recovery of Pasture Seed Ingested by Ruminants. 1. Seed of Six Tropical Pasture Species Fed to Cattle, Sheep and Goats. Australian Journal of Experimental Agriculture, 27, $239-246$. http://www.publish.csiro.au/paper/EA9870239 http://dx.doi.org/10.1071/EA9870239

[13] Silva, T.O. (2008) Dispersal, Germination and Persistence of Tropical Fabaceae Forage through the Faeces Bovine. Ph.D. Dissertation, Seropédica, Federal Rural University of Rio de Janeiro.

[14] Silva, T.O. (2013) Study for Fabaceae Dispersion in Pastures by Small Ruminants. Ph.D. Thesis, Campos dos Goytacazes, University of North Fluminense Darcy Ribeiro.

[15] Bocchese, R.A., de Oliveira, A.K.M. and Laura, V.A. (2008) Cecropia pachystachya (Cecropiaceae) Seeds Germination Patterns before and after Their Passage by the Digestive Tract of Seed Dispersal Birds. Revista de Biologia e Ciência da Terra, 8, 19-26. http://eduep.uepb.edu.br/rbct/sumarios/pdf/3cecropia.pdf

[16] Nakao, E.A. and Cardoso, V.J.M. (2010) Recovery and Germination of Legume Seeds Passed through the Digestive Tract of Bovine Cattle. Biota Neotropica, 10, 189-195. http://www.scielo.br/pdf/bn/v10n3/22.pdf http://dx.doi.org/10.1590/S1676-06032010000300022

[17] Braz, S.P., Nascimento, J.R.D. and Cantarutti, R.B. (2002) Quantitative Aspects of Nutrients Recycling in the Feces of Bovines Grazing a Pasture of Brachiaria decumbens in the Zona da Mata Region of Minas Gerais. Revista Brasileira de Zootecnia, 31, 858-865. http://www.scielo.br/pdf/rbz/v31n2s0/21274.pdf http://dx.doi.org/10.1590/S1516-35982002000400008

[18] Lisboa, C.A.V., de Medeiros, R.B., de Azevedo, E.B., Patino, H.O., Carlotto, S.B. and Garcia, R.P.A. (2009) Germination of Capim-Annoni-2 (Eragrostis plana Ness) Seeds Recovered in Bovine Feces. Revista Brasileira de Zootecnia, 38, 405-410. http://www.scielo.br/pdf/rbz/v38n3/a01v38n3.pdf http://dx.doi.org/10.1590/S1516-35982009000300001

[19] Ramos, M.E., Robles, A.B. and Castro, J. (2006) Efficiency of Endozoochorous Seed Dispersal in Six Dry-Fruited Species (Cistaceae): From Seed Ingestion to Early Seedling Establishment. Plant Ecology, 185, 97-106. http://link.springer.com/article/10.1007/s11258-005-9087-y http://dx.doi.org/10.1007/s11258-005-9087-y

[20] Gardener, C.J., McIvor, J.G. and Jansen, A. (1993) Passage of Legume and Grass Seeds through the Digestive Tract of Cattle and Their Survival in Faeces. Journal of Applied Ecology, 30, 63-74. http://www.jstor.org/stable/2404271 http://dx.doi.org/10.2307/2404271

[21] Gardener, C.J., McIvor, J.G. and Jansen, A. (1993) Survival of Seeds of Tropical Grasslands Species Subjected to Bovine Digestion. Journal of Applied Ecology, 30, 75-85. http://www.jstor.org/stable/2404272 http://dx.doi.org/10.2307/2404272 
Scientific Research Publishing (SCIRP) is one of the largest Open Access journal publishers. It is currently publishing more than 200 open access, online, peer-reviewed journals covering a wide range of academic disciplines. SCIRP serves the worldwide academic communities and contributes to the progress and application of science with its publication.

Other selected journals from SCIRP are listed as below. Submit your manuscript to us via either submit@scirp.org or Online Submission Portal.
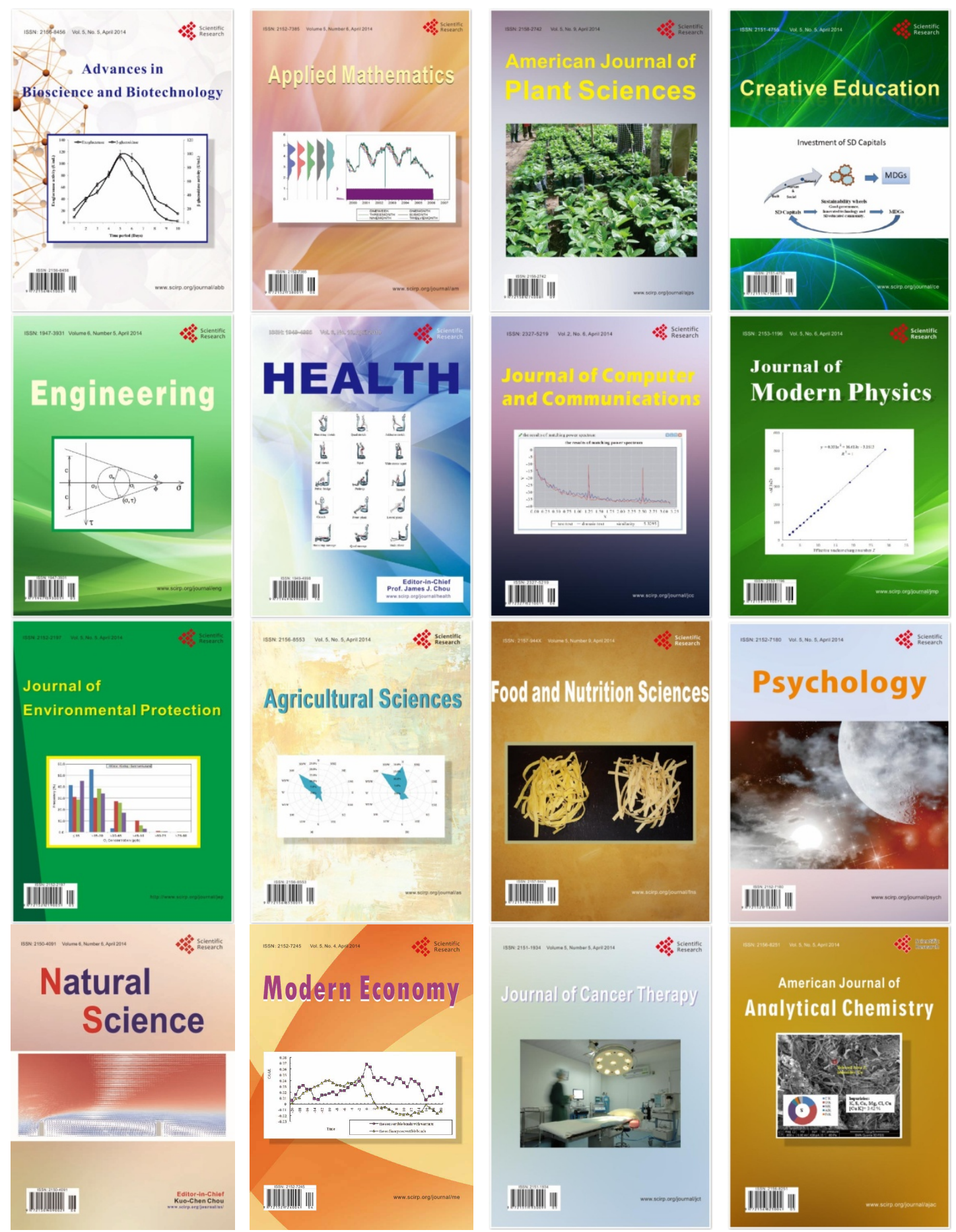